\title{
Interaction between environmental and socioeconomic determinants for cutaneous leishmaniasis risk in Latin America*
}

\author{
Ana Nilce. S. Maia-Elkhoury, ${ }^{1}$ Daniel Magalhães Lima, ${ }^{2}$ Oscar Daniel Salomón, ${ }^{3}$ \\ Lia Puppim Buzanovsky, ${ }^{2}$ Martha Idalí Saboyá-Díaz, ${ }^{4}$ Samantha Y.O.B. Valadas, ${ }^{1}$ and \\ Manuel J. Sanchez-Vazquez ${ }^{2}$
}

Suggested citation Maia-Elkhoury AN, Magalhães Lima D, Salomón OD, Puppim Buzanovsky L, Saboyá-Díaz MI, Valadas SY, et al. Interaction between environmental and socioeconomic determinants for cutaneous leishmaniasis risk in Latin America. Rev Panam Salud Publica. 2021;45:e83. https://doi.org/10.26633/RPSP.2021.83

ABSTRACT Objective. Determine and characterize potential risk areas for the occurrence of cutaneous leishmaniasis (CL) in Latin America (LA).

Method. Ecological observational study with observation units defined by municipalities with CL transmission between 2014-2018. Environmental and socioeconomic variables available for at least $85 \%$ of the municipalities were used, combined in a single database, utilizing the $\mathrm{R}$ software. The principal component analysis methodology was combined with a hierarchical cluster analysis to group clusters of municipalities based on their similarity. The V-test was estimated to define the positive or negative association of the variables with the clusters and separation by natural breaks was used to determine which ones contributed the most to each cluster. Information on cases was also incorporated in the analyses to attribute CL risk for each cluster.

Results. This study included 4,951 municipalities with CL transmission (36.5\% of the total in LA) and seven clusters were defined by their association with 18 environmental and socioeconomic variables. The historical risk of $\mathrm{CL}$ is positively associated with the Amazonian, Andean and Savannah clusters in a decreasingly manner; and negatively associated with the Forest evergreen, Forest/crop and Forest/populated clusters. The Agricultural cluster did not reveal any association with the CL cases.

Conclusions. The study made it possible to identify and characterize the CL risk by clusters of municipalities and to recognize the epidemiological distribution pattern of transmission, which provides managers with better information for intersectoral interventions to control CL.

Keywords C Cutaneous leishmaniasis; cluster analysis; Latin America.

Cutaneous leishmaniasis (CL) is a disease caused by more than 20 species of parasites of the genus Leishmania and is transmitted by vectors of the Psychodidae family (1). In the Region of the Americas, it is a zoonosis, and Leishmania sp has been found as an infectious agent in different species of wild mammals (2). It is a public health problem, with worldwide distribution in 88

\footnotetext{
* Official English translation from the original Spanish manuscript made by the Pan American Health Organization. In case of discrepancy, the original version shall prevail. Access to original manuscript: https://doi.org/10.26633/ RPSP.2021.49

1 Pan American Health Organization, Rio de Janeiro, Brazil. $\triangle$ Ana Nilce. S. Maia-Elkhoury aelkhoury@paho.org
}

\footnotetext{
2 Pan American Foot and Mouth Disease Center, Pan American Health Organization, Rio de Janeiro, Brazil.

3 Tropical Medicine National Institute, Puerto Iguazú, Argentina.

4 Pan American Health Organization, Washington, D.C., United States of the Americas.
} 
countries. In the American continent, it is endemic in 18 countries, with an annual record of approximately 46,000 cases with different clinical manifestations, of which localized CL is the most frequent $(3,4)$.

CL continues to be one of the neglected infectious diseases (NIDs) of great importance due to its strong association with poverty $(3,5)$. The fight against leishmaniasis is closely related to the sustainable development goals (SDG), especially SDG 3 (health and well-being) and those that are possible determinants for the occurrence of the disease, such as SDG 1 (reduction of poverty), SDG 2 (promote sustainable agriculture), SDG 6 (access to water and sanitation), SDG 8 (economic growth and full and productive employment), SDG 13 (climate change) and SDG 15 (protect terrestrial ecosystems). Therefore, an integrated approach, both programmatic and multisectoral, is required to implement effective health policies and reduce damage to affected populations (6).

The occurrence of CL is determined by the exposure of human beings (usually by economic and social activities) in contexts where there are climatic and ecological conditions for the presence of vectors, parasites and reservoirs involved in the transmission. These contexts modulate the increase in the level of human exposure (7), they pressure the adaptation of vector species to new ecological niches, created by anthropogenic interventions in environments favorable to vector proliferation (8), and increase the interactions between reservoirs and parasites; in this way, they contribute to the maintenance of the disease transmission cycle (2).

The close relationship between climate change and the emergence and re-emergence of some NIDs, including leishmaniasis, has been documented in various parts of the world (9). For example, recent studies showed the likely future expansion of habitats for cutaneous leishmaniasis vectors in South America (10) and Brazil (11). Likewise, the increased risk of exposure and occurrence of leishmaniasis has been documented in populations living in poverty, mainly related to the characteristics of the dwellings (proximity to forests, conditions that favor the entry of the vector into the home, overcrowding, etc.), low coverage of access to water and sanitation services, illiteracy and difficulties in understanding transmission and prevention processes, among others (5). A study on environmental and socioeconomic determinant factors for the occurrence of CL in Brazil found that temperature, presence of forests, types of vegetation, degree of urbanization, sanitation, human development, income, population and rural areas, cultural habits, professional occupation, agricultural activities, deforestation and mining were the most relevant (12). The present study aims to determine and characterize the potential risk areas for the occurrence of CL in Latin America (LA) by using variables related to environmental and socioeconomic determinants.

\section{MATERIALS AND METHODS}

\section{Type, period and target population}

It is an ecological observational study. The observation units were the 4,951 municipalities in LA (36.5\% of the total municipalities in LA) where there was transmission of CL in the period of 2014 to 2018, according to records of the regional information system (SisLeish) (13). This system consolidates annually the CL occurrence data, by municipality, notified by the ministries of health (13).

\section{Analysis strategy}

First, those environmental and socioeconomic variables that could be associated with the risk of CL were identified. Next, through a multivariate analysis methodology, hierarchical clusters of municipalities that had similar characteristics based on environmental variables were created. This multivariate analysis was repeated with the inclusion of socioeconomic variables. Subsequently, the results of the two hierarchical clustering approaches, with or without socioeconomic variables, were evaluated to decide which one best characterized the risk of CL. Finally, the risk distribution for each of the clusters was explored, to characterize them according to the historical risk.

\section{Environmental and socioeconomic variables}

Based on the main determinants for CL and for other NIDs $(12,14)$, a search was carried out for data that were available for at least $85 \%$ of the municipalities with transmission of the disease in LA. Matrix data of temperature, altitude, precipitation, presence of forests, types of vegetation, agricultural and mining activities were found (14-17), as well as tabular data of sanitation, water, overcrowding and illiteracy compiled by a previous study, which used data from the population and housing censuses of the countries (18). Table 1 describes the variables included in the study, the sources and the metadata. Through the geographical limits of the municipalities and, with the use of the exactextractr (19) package, of the R software (20), the matrix data were compiled and combined in a single database together with the tabular data.

\section{Multivariate analysis by hierarchical clustering}

To characterize the municipalities based on the variables identified above and to create the municipal clusters, the principal component analysis methodology was combined with hierarchical cluster analysis, maintaing the five first dimensions (21-23). The clusters are a set of municipalities with characteristics similar to each other but, at the same time, with the greatest possible differentiation with municipalities included in other clusters. In this procedure, the number of the resulting clusters is a flexible parameter defined by the analyst (21). Therefore, five to ten possibilities were tested; and it was observed that seven clusters was an adequate number to achieve discrimination according to the objectives of the study.

A multivariate analysis was performed by hierarchical clustering for the environmental variables (approach A) and another for the joint analysis of the environmental and socioeconomic variables (approach B).

As result, an exhaustive discrimination of statistical (non-spatial) clusters of municipalities was obtained based on their similarity concerning the greater or lesser degree of participation of the risk variables. For this purpose, the V-test was estimated, which represents the positive or negative association 
TABLE 1. Description of the variables, sources and metadata included in the study

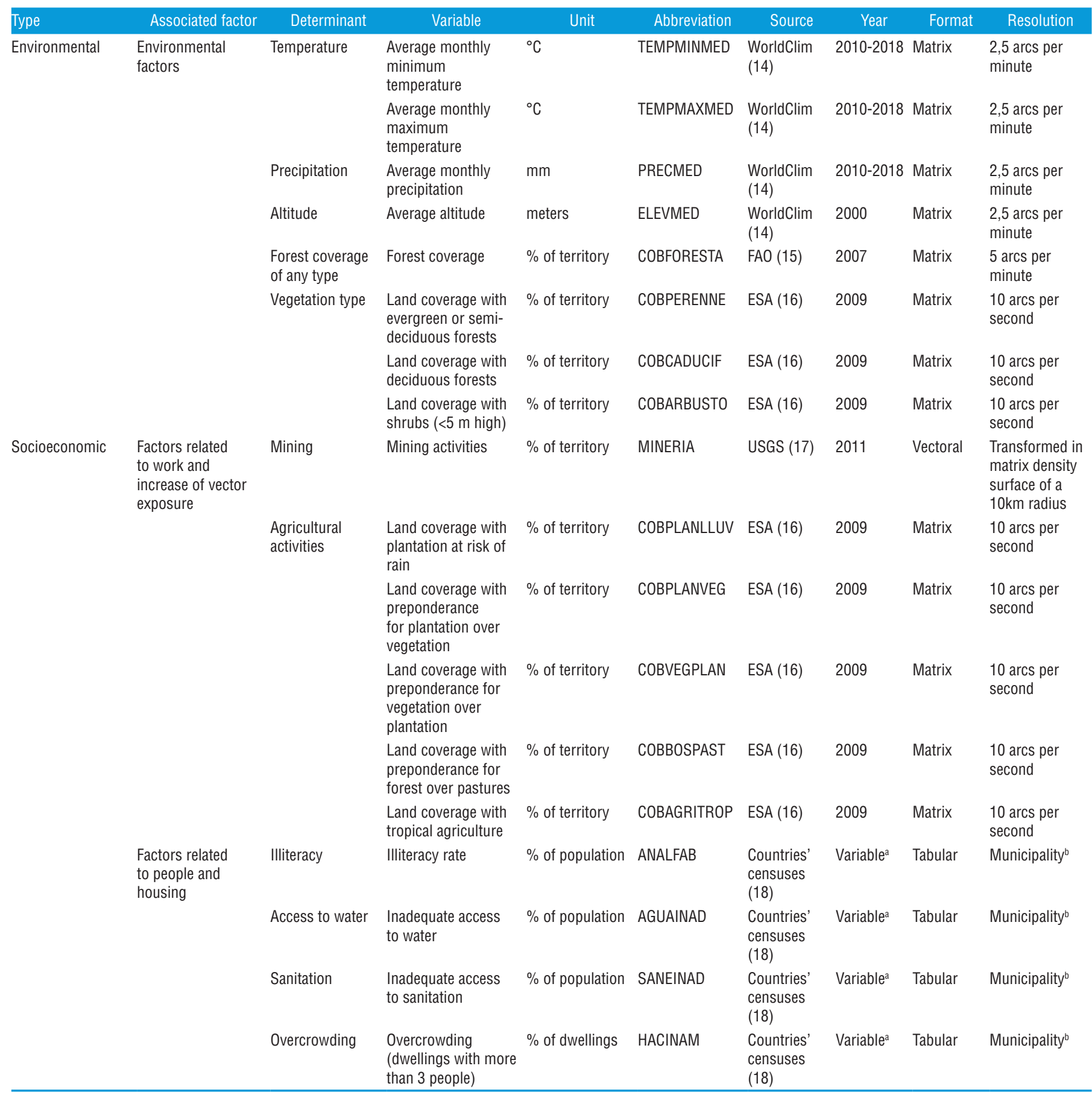

Data compiled by a previous study using the most recent population and housing census data for each country published between 2000 and 2012 (18).

bFor the purposes of the study, the provinces, districts, municipalities, cantons, etc., according to the nomenclature and structure in each country, were generically called municipalities (18).

FAO, Food and Agriculture Organization of the United Nations; ESA, European Space Agency; USGS, United States Geological Survey.

Source: elaborated by authors with results from the study and with the permission of the authors of the original study from which the data on the people and housing factors were obtained.

of the variables with the clusters and was also used as an indicator of the relative importance of this factor in the cluster. Natural breaks were used to determine the variables that contributed the most to each cluster $(24,25)$. Thus, the absolute values of the V-tests for each cluster were divided into five groups and the variables with the highest values were selected to interpret the main characteristics in each one.

\section{Discrimination of the most appropriate approach}

The two hierarchical cluster results were evaluated to decide which approach (i.e., with or without socioeconomic variables) best characterized CL risk. Thus, the variables that most contributed to the characterization of the clusters were compared with both approaches to determine the relevance of 
incorporating the socioeconomic variables, and their geographical distribution.

\section{Risk determination by cluster}

Once the approach was defined, and with the final results of the clusters, we proceeded to identify them according to their risk level. For this, the CL cases reported in SisLeish between 2014 and 2018 (13) were incorporated as an illustrative variable in the multivariate analysis by hierarchical clusters. Although this variable did not participate in the delimitation of the clusters, the association of CL risk with the cluster is presented based on the result of its V-test (23).

\section{RESULTS}

Of the 4,985 municipalities with CL transmission in 16 countries of LA, 4,951 municipalities were included in the study, because complete information was found on the 18 selected variables for these municipalities.

\section{Result of the discrimination by the most appropriate approach}

As a result of the multivariate analyses by hierarchical clustering of municipalities, seven clusters were defined by their association with environmental variables, approach A (table 2 and figure 1), and seven defined by their association with environmental and socioeconomic variables, approach B (table 3 and figure 1). The comparison between the two approaches revealed that the inclusion of the socioeconomic variables allowed more exhaustive discrimination of the clusters, and a more comprehensive interpretation of the CL transmission risk. This can be clearly seen in the discrimination achieved in the southern half of Brazil with approach B (versus A). Thus, the socioeconomic variables related to sanitation, education, drinking water and overcrowding are key to the formation of the Forest/crop and Amazonian clusters. On the other hand, the socioeconomic variables related to labor and the level of exposure, such as agricultural activities, are key to the formation of the Forest/populated and Forest evergreen clusters. These clusters help to differentiate the areas where there is a risk of $\mathrm{CL}$ occurrence and provide knowledge of the factors that contribute to such risk. Thus, Approach B, with environmental and socioeconomic variables, was considered the most appropriate because it provides more information on the characterization of the risk of CL occurrence.

The distribution of CL cases by municipality in the period of 2014-2018 is presented in figure 2. The historical risk of CL appears to be positively associated with the Amazonian (V-test: 11.44), Andean (V-test: 3.25) and Savannah (V-test: 3.08) clusters, in a decreasingly manner; and negatively associated with

TABLE 2. Environmental ${ }^{a}$ variables with greater weight according to the V-test in each cluster

\begin{tabular}{|c|c|c|c|c|c|c|}
\hline Cluster & Variable & V-test & Cluster mean & General mean & Cluster SD & General SD \\
\hline \multirow[t]{3}{*}{$\mathrm{A} 1$} & ELEVMED & 53.7 & 2899.8 & 644.6 & 657.7 & 701.8 \\
\hline & COBFORESTA & -15.1 & 17.3 & 39.9 & 14.4 & 25.1 \\
\hline & TEMPMINMED & -45.2 & 7.0 & 18.0 & 3.8 & 4.1 \\
\hline \multirow[t]{2}{*}{ A2 } & ELEVMED & 18.1 & 1032.6 & 644.6 & 460.5 & 701.8 \\
\hline & COBPERENNE & -11.3 & 0.2 & 0.3 & 0.2 & 0.3 \\
\hline \multirow[t]{4}{*}{ A3 } & COBPERENNE & 55.5 & 0.7 & 0.3 & 0.2 & 0.3 \\
\hline & COBCADUCIF & -14.4 & 0.0 & 0.0 & 0.0 & 0.1 \\
\hline & PRECMED & -20.4 & 102.8 & 131.2 & 30.9 & 56.9 \\
\hline & COBARBUSTO & -22.3 & 0.0 & 0.1 & 0.0 & 0.1 \\
\hline A4 & COBARBUSTO & 52.4 & 0.4 & 0.1 & 0.1 & 0.1 \\
\hline A5 & COBPERENNE & -8.1 & 0.2 & 0.3 & 0.1 & 0.3 \\
\hline \multirow[t]{5}{*}{ A6 } & TEMPMAXMED & 23.8 & 30.8 & 28.6 & 1.8 & 3.6 \\
\hline & TEMPMINMED & 20.1 & 20.0 & 18.0 & 2.0 & 4.1 \\
\hline & PRECMED & -14.7 & 110.3 & 131.2 & 35.5 & 56.9 \\
\hline & ELEVMED & -18.4 & 321.1 & 644.6 & 216.7 & 701.8 \\
\hline & COBPERENNE & -20.4 & 0.2 & 0.3 & 0.1 & 0.3 \\
\hline \multirow[t]{4}{*}{ A7 } & COBFORESTA & 41.0 & 73.3 & 39.9 & 18.7 & 25.1 \\
\hline & PRECMED & 37.8 & 201.1 & 131.2 & 70.5 & 56.9 \\
\hline & TEMPMINMED & 27.7 & 21.6 & 18.0 & 1.6 & 4.1 \\
\hline & TEMPMAXMED & 22.4 & 31.2 & 28.6 & 1.5 & 3.6 \\
\hline
\end{tabular}

AAll variables presented had a $p<0.001$ value.

SD: standard deviation.
Source: elaborated by authors with results from the study. 
FIGURE 1. Spatial distribution of clusters formed by environmental variables in municipalities with CL transmission, approach A (left) and of environmental and socioeconomic variables in municipalities with CL transmission between 2014 and 2018 in Latin America, approach B (right)
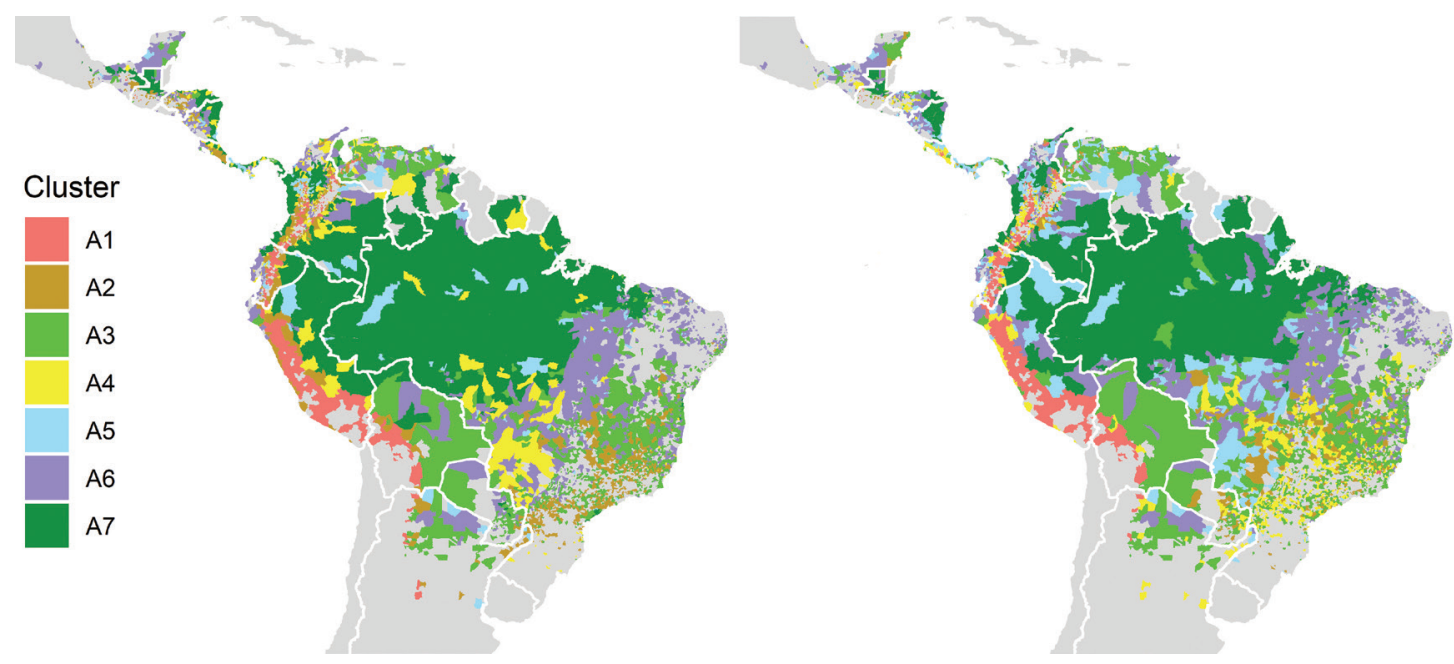

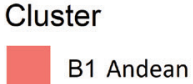

B2 Forest/populated

B3 Forest evergreen

B4 Forest/crop

B5 Savannah "Cerrado"

B6 Agricultural

B7 Amazonian

Source: elaborated by the authors with the results from the study

the Forest evergreen (V-test: -5.52), Forest/crop (V-test: -4.66) and Forest/populated (V-test: -3.35) clusters. The Agricultural cluster did not reveal any association with the CL cases.

\section{DISCUSSION}

The World Health Organization included leishmaniasis among the 20 diseases that disproportionately affect populations living in poverty, especially in tropical and subtropical areas (26). Understanding the factors associated with the occurrence of CL has been the subject of multiple studies, including some approximations for the analysis of climatic factors and environmental conditions in the Americas (27).

In the present study, the incorporation of variables related to people's living conditions (access to drinking water, basic sanitation, overcrowding, education, agricultural and mining activities) contributed to a better characterization of the municipalities clusters with a risk of CL transmission in Latin America, when combined with environmental variables related to temperature, precipitation, altitude and type of vegetation.

Although these variables of living conditions are more frequently included in the transmission risk analysis of other NIDs, such as in soil-transmitted helminth infections or trachoma (18, 28 ), on a more disaggregated level such as municipalities, the specific inclusion of these variables for the analysis of factors associated with CL transmission is not frequent. This analytical approach at the municipal level allowed the characterization of seven clusters of CL transmission, making it a useful tool to support the development of surveillance actions, and prevention and control interventions focused on social, economic, epidemiological and environmental contexts of the affected communities.

In areas with autochthonous CL cases, environmental factors enable the parasitic cycle and its continuity over time, while social variables determine the probability of transmission to humans by modulating their exposure and vulnerability, and both are integrated into the particular socio-environmental context of each area $(12,29)$. Therefore, the general characteristics of each cluster (Table 3 ) allow the identification of different risk of outbreak scenarios according to human interaction with the environment. These scenarios are useful to better design actions for monitoring, generate early warnings and define mitigation activities, even in areas without cases.

The Amazonian cluster, the one with the greatest association with CL cases, presents foci of high incidence due to proximity to the CL sylvatic cycle. This is reflected, for example, in the occurrence of cases in the municipalities of Tumaco (Colombia) and in Waslala, Rancho Grande, San José de Bocay and Cua (Nicaragua). However, in this cluster, there are also areas of lower incidence associated with deforestation and dispersed human settlements. In this cluster, outbreaks and isolated cases are originated from the "intrusion" of human beings into the forest during extractive, military, research and recreational activities. However, there is also human intrusion by illegal activities, causing underreporting of cases and difficulty in locating the precise site of transmission. In temporary or semi-permanent human camps, the risk of CL is increased by overcrowding, exposure in riparian forests and level of illiteracy $(30,31)$. This is a cluster with very dynamic epidemiological scenarios, which require continuous monitoring due to the massive change in land use, the growth of cities bordering the jungle and large-scale fires, which generates pressure for the dispersal and adaptation of the CL transmission cycle to anthropized environments $(32,33)$.

In the Andean cluster, physical barriers and altitude differences generate great heterogeneity of ecosystems in quite reduced areas, which result in the variety of parasites, vectors and reservoirs associated with this cluster. For example, L. peruviana has endemic transmission in communities of the semi-arid highlands and there are epidemic foci of L. guyanensis due to interventions in the tropical high-altitude rainforest. In some municipalities, such as those of Tolima (Colombia), the transmission usually occurs at 1,000-2,000 meters above sea level, although there are records of transmission in other regions at 
TABLE 3. General characteristics of the clusters, environmental and socioeconomic variables ${ }^{\mathrm{a}}$ with the greatest weight ${ }^{\mathrm{b}}$ according to the V-test in each one

\begin{tabular}{|c|c|c|c|c|c|c|c|c|}
\hline Cluster & $\mathrm{N} .^{\circ}$ of municipalities & General characteristics & Variable & V-test & Cluster mean & $\begin{array}{c}\text { General } \\
\text { mean }\end{array}$ & Cluster SC & General SD \\
\hline \multirow{2}{*}{ Andean } & \multirow{2}{*}{333} & \multirow{2}{*}{$\begin{array}{l}\text { Inter-Andean valleys, slopes of } \\
\text { the Andes, presence of mining } \\
\text { and areas with inadequate access } \\
\text { to water }\end{array}$} & MINERIA & 25 & 21.2 & 5.1 & 27.6 & 12.1 \\
\hline & & & TEMPMAXMED & -46.8 & 19.6 & 28.6 & 3.2 & 3.6 \\
\hline \multirow[t]{2}{*}{ Forest/populated } & \multirow[t]{2}{*}{311} & \multirow{2}{*}{$\begin{array}{l}\text { Areas with a predominance of } \\
\text { forests, less presence of tropical } \\
\text { agriculture and plantations. } \\
\text { Presence of urban areas and } \\
\text { communities in the process of } \\
\text { urbanization }\end{array}$} & BOSPASTO & 54.5 & 0.1 & 0 & 0.1 & 0 \\
\hline & & & AGRITROP & -8.1 & 0.3 & 0.4 & 0.3 & 0.4 \\
\hline \multirow[t]{4}{*}{ Forest evergreen } & \multirow[t]{4}{*}{1347} & \multirow{4}{*}{$\begin{array}{l}\text { Areas with evergreen forest } \\
\text { coverage and extensive } \\
\text { geographic continuity }\end{array}$} & COBPERENNE & 55.3 & 0.7 & 0.3 & 0.2 & 0.3 \\
\hline & & & PLANTACLLUV & -22 & 0 & 0.1 & 0 & 0.1 \\
\hline & & & VEGPLANTAC & -27.8 & 0.1 & 0.2 & 0.1 & 0.1 \\
\hline & & & PLANTACVEG & -31.8 & 0.1 & 0.2 & 0.1 & 0.2 \\
\hline \multirow{6}{*}{ Forest/crop } & \multirow{6}{*}{850} & \multirow{6}{*}{$\begin{array}{l}\text { Wooded areas, tropical crops } \\
\text { and localities of medium } \\
\text { development, and remnant } \\
\text { patches of tropical forest }\end{array}$} & TEMPMINMED & -14.3 & 16.2 & 18 & 2.3 & 4.1 \\
\hline & & & HACINAM & -15.6 & 0 & 0.1 & 0 & 0.1 \\
\hline & & & COBPERENNE & -15.7 & 0.2 & 0.3 & 0.2 & 0.3 \\
\hline & & & AGUAINAD & -16.7 & 0.1 & 0.2 & 0.1 & 0.2 \\
\hline & & & ANALFAB & -17.6 & 0.1 & 0.2 & 0.1 & 0.1 \\
\hline & & & SANEINAD & -17.9 & 0.1 & 0.2 & 0.1 & 0.2 \\
\hline \multirow[t]{3}{*}{ Savannah "cerrado" } & \multirow[t]{3}{*}{505} & \multirow{3}{*}{$\begin{array}{l}\text { Shrub coverage and deciduous } \\
\text { forests. } \\
\text { On the margins of the Amazonian } \\
\text { cluster, biological reserves. or in } \\
\text { valleys at the foot of humid tropical } \\
\text { forest } \\
\text { Areas with poor access to water, } \\
\text { sanitation, and education }\end{array}$} & COBARBUSTO & 41 & 0.3 & 0.1 & 0.2 & 0.1 \\
\hline & & & COBCADUCIF & 36.6 & 0.1 & 0 & 0.2 & 0.1 \\
\hline & & & COBPERENNE & -15.9 & 0.1 & 0.3 & 0.1 & 0.3 \\
\hline \multirow{3}{*}{ Agricultural } & \multirow{3}{*}{1066} & \multirow{3}{*}{$\begin{array}{l}\text { Areas with tropical agricultural } \\
\text { activities, such as cultivated } \\
\text { areas at risk of rain, high average } \\
\text { temperatures and low altitude, } \\
\text { tropical crops, and a lower } \\
\text { proportion of forest areas and } \\
\text { pasture. }\end{array}$} & BOSPASTO & -11.9 & 0 & 0 & 0 & 0 \\
\hline & & & ELEVMED & -17.3 & 315.5 & 644.6 & 267.4 & 701.8 \\
\hline & & & COBPERENNE & -17.6 & 0.2 & 0.3 & 0.1 & 0.3 \\
\hline \multirow[t]{8}{*}{ Amazonian } & \multirow[t]{8}{*}{539} & \multirow{8}{*}{$\begin{array}{l}\text { Great vegetation coverage, } \\
\text { average temperatures and high } \\
\text { precipitation that form the } \\
\text { Amazonian basin and the humid } \\
\text { tropical forest. } \\
\text { Presents a high association with } \\
\text { the occurrence of CL cases and } \\
\text { an extensive and continuous } \\
\text { geographic area with inadequate } \\
\text { access to water and sanitation, } \\
\text { and with illiteracy }\end{array}$} & HACINAM & 35.3 & 0.2 & 0.1 & 0.1 & 0.1 \\
\hline & & & PRECMED & 34.2 & 210.4 & 131.2 & 76.7 & 56.9 \\
\hline & & & AGUAINAD & 32.7 & 0.4 & 0.2 & 0.2 & 0.2 \\
\hline & & & COBFORESTA & 32.3 & 72.9 & 39.9 & 21.2 & 25.1 \\
\hline & & & SANEINAD & 30.6 & 0.4 & 0.2 & 0.2 & 0.2 \\
\hline & & & TEMPMINMED & 22.6 & 21.7 & 18 & 1.7 & 4.1 \\
\hline & & & ANALFAB & 20.8 & 0.2 & 0.2 & 0.1 & 0.1 \\
\hline & & & TEMPMAXMED & 16.2 & 31 & 28.6 & 1.7 & 3.6 \\
\hline
\end{tabular}

aThe analyzes of all the environmental and socioeconomic variables that had statistical significance in relation to the V-test for each cluster are detailed in the Supplementary Information. 'AAll the variables presented had a $p<0.001$ value.

Source: prepared by the authors with the results of the study.

higher altitudes, possibly favored by climate change. Mining, in this context, is a risky activity for the CL occurrence in humans because it increases contact with enzootic cycles during work and in the camps where workers are housed, as occurred with bartonellosis transmitted by Phlebotominae in the construction of the Central Railroad of Peru. In this cluster, epidemic or endemic, peridomestic and domestic transmission also occurs in recently deforested areas of rural localities for subsistence 
FIGURE 2. Spatial distribution of CL cases in Latin America reported between 2014 and 2018 on a logarithmic base 10 scale

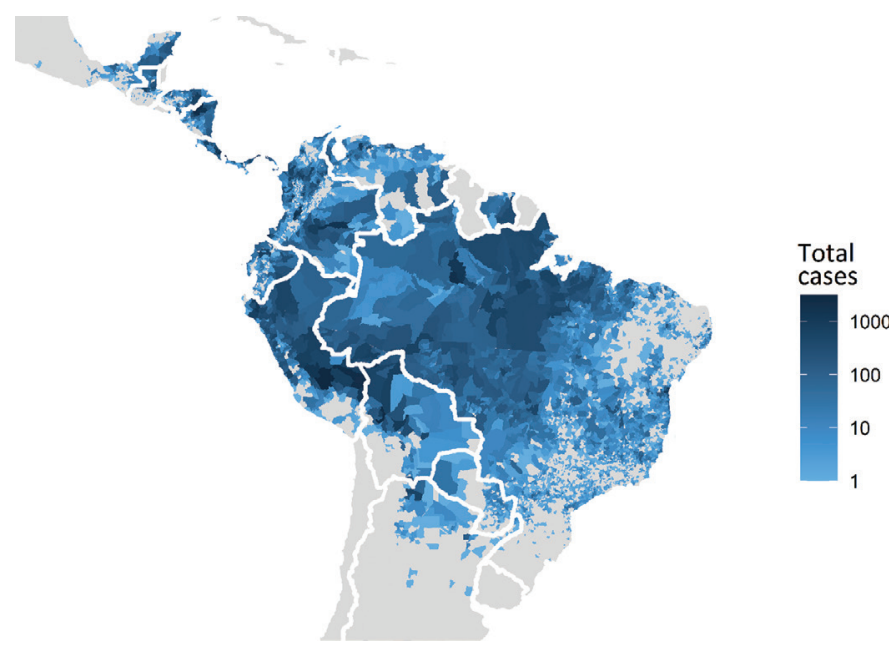

Source: elaborated by the authors with the results from the study.

farming and agricultural exploitation, such as coffee plantations in the municipality of Rovira (Colombia) $(34,35)$.

The areas delimited by the Savannah cluster are usually transition zones, with the presence of dispersed rural communities, such as the municipalities of the state of Pará (Brazil) or Chocó (Colombia). In the CL foci of moderate and sustained intensity, the age and sex distribution of the cases suggests a peridomestic transmission even in ancient settlements close to the sylvatic cycle. However, socio-environmental alterations in "hot spots" can generate outbreaks of great magnitude, as resulted of the gas exploitation and transportation in La Convención in Peru $(36,37)$.

In this study, the Agricultural cluster did not present a positive or negative association with the registered CL cases. The illiteracy rate characterizes, once again, the social determination of the exposed communities and their management capacity. However, these results do not imply a low risk of transmission, since it involves municipalities with important records of CL such as Teolândia, in the cocoa area of Bahia (Brazil), regions of Amazonian influence with extractive activities, and the expansion of the agricultural frontier such as in Rio Branco (Brazil) and Tambopata, Madre de Dios (Peru) or Choluteca in Honduras where atypical CL due to L. infantum occurs. This cluster also involves areas with an intermediate endemic transmission or with limited outbreaks, where the peridomestic risk is related to proximity to waterways, animal husbandry and patches of vegetation such as bamboo and bananas, as in Sapucaia (Brazil) $(38,39)$.

The Forest clusters evergreen, crop and populated, in that order, presented a negative association with the registered CL cases, in an intensity consistent with the degree of anthropic intervention in the environment and high and intermediate rates of CL in few municipalities. The Forest/crop cluster includes established communities, on lands already deforested in large areas, but where remnants of tropical forest and the permanence of the sylvatic cycle in areas that are not profitable to deforest can generate "edges" with sustained peridomestic transmission and important local outbreaks. These features are observed in rural or rural-urban communities of Orán (Argentina), Falan (Colombia) or Ferreñafe (Peru), where the increase of cases was associated with the progression of epidemic outbreaks from regions neighboring zones with the colonization of vectors adapted to anthropic environments or ecotourism areas with CL incidence in indigenous populations $(40,41)$.

The Forest evergreen cluster, together with the Amazonian, presents the greatest spatial continuity and number of municipalities, mainly in the Plurinational State of Bolivia and the Bolivarian Republic of Venezuela, although it is, in turn, the one that includes the least demographic information. This cluster registers sporadic transmission by the entrance in areas of forest fragmentation, suggested by the higher proportion of CL cases in males, as in Chapare (Bolivia) or Campinápolis and Mato Grosso (Brazil). This fragmentation, depending on its magnitude, original environment and quality of secondary vegetation or commercial farming, can generate "microfocal" risk by concentrating vectors and CL reservoirs or by diluting until their transmission is extinguished. Accelerated deforestation, migration, and colonization processes contribute to social exclusion factors that modulate environmental risk and vulnerability to extreme weather events, as observed in Talamanca (Costa Rica) $(42,43)$.

The Forest/populated cluster, presents a negative association with the CL cases of greater magnitude, it includes urbanized areas and unplanned urbanization areas with residual or secondary vegetation and specific deforestation to allow new settlements, such as the municipalities of Barra do Garças (Brazil), Cimitarra (Colombia) and Othón Pompeyo Blanco (Mexico) $(44,45)$. The population exposed to this peri-urban risk includes both those that occupy areas with low land profitability, already weakened by the inequities of the system, and new real estate developments concerning a "return to nature" culture, with their own resources and greater media presence.

The limitations of the study are inherent to the data sources available for analysis on a municipality scale, such as population and housing censuses, which in some countries are more than 15 years old, or due to the unavailability of quality data or environmental and socioeconomic variables, such as income and differentiation between urban and rural areas. Another limitation is that the municipality scale is different from the CL foci operational scale and from the identification of determinants of epidemic outbreaks, which are restricted in time and space. Moreover, regarding the surveillance and registration of CL cases, the notification site may be different from the transmission site (for example, cases that occur in soldiers, forced migrants or seasonal migrants), which requires a fluent communication system between the case production, reception and diagnosis sites. There are also limitations and possible biases due to underreporting associated with a lack of accessibility and diagnostic sensitivity of the health system, which increases the vulnerability of the already vulnerable populations.

\section{Conclusions}

The study made it possible to identify and characterize the CL risk by clusters of municipalities. This contributed to a better understanding of the epidemiological pattern of the transmission distribution in order to provide leishmaniasis programme managers with better information for the surveillance and control of the disease. The cluster analysis based on socio-environmental determinants at the municipal level and their association with focal risks of CL epidemic transmission demonstrates that simultaneous actions are required from multiple 
sectors, not only from the health sector, to control and mitigate the impact of zoonotic diseases like CL. The variables involved in the characterization of the clusters show their direct relationship with the sustainable development agenda, so it is necessary that the managers and health professionals involved in the surveillance and control actions of leishmaniasis in Latin America plan their interventions taking into account the determinants and characterization of the different clusters, the risk factors and the occurrence of disease or its potential transmission in areas that, for now, remain silent or without CL records.

Author's contribution. ANSME, SYOBV, and MJSV conceived the original study; DML, LPB, MJSV analyzed the data; ANSME, DML, ODS, LPB, MISD, MJSV wrote the manuscript; ANSME, MISD, SYOBV reviewed the manuscript. all the authors approved the final version.

Acknowledgements. The authors thank Santiago Nicholls (PAHO regional advisor on neglected infectious diseases) for his critical review of the manuscript, Patrícia Segurado (PAHO regional advisor on water and sanitation), Henry Hernández (PAHO advisor on environmental public health) and Marcelo Korc (chief of the PAHO Climate Change and Environmental Determinants of Health Unit), for their relevant contributions. They also thank ESA and ESA Globcover Project led by MEDIAS France/POSTEL for the spatial data provided.

\section{Conflicts of interest. None declared by the authors.}

Financing. The authors did not receive specific funding for this work. This work was carried out by PAHO/WHO through the biennial work plan of the Regional Leishmaniasis and Neglected Infectious Diseases Programmes. Funders were not involved in the study, design, data collection or analysis, publication decision, or manuscript preparation.

Disclaimer. Authors hold sole responsibility for the views expressed in the manuscript, which may not necessarily reflect the opinion or policy of the Pan-American Journal of Public Heatlh or the Pan American Health Organization (PAHO).

\section{REFERENCES}

1. World Health Organization. Global leishmaniasis update, 2006-2015: a turning point in leishmaniasis surveillance. Weekly epidemiological record N. ${ }^{\circ}$ 38. 2017;92:557-572. Available at: https://www.who. int/leishmaniasis/resources/who_wer9238/en/

2. Roque ALR, Jansen AM. Wild and synanthropic reservoirs of Leishmania species in the Americas. Int J Parasitol Parasites Wildl. 2014;3(3):251-262. Doi: 10.1016/j.ijppaw.2014.08.004

3. World Health Organization. Global leishmaniasis surveillance, 2017-2018, and first report on 5 additional indicators. Weekly epidemiological record N. ${ }^{\circ}$ 25. 2020; 95:265-280. Available at: https:// www.who.int/publications/i/item/who-wer9525

4. Pan American Health Organization. Leishmaniasis: epidemiological report in the Americas. [Internet]. Washington, D.C.: OPS; 2019 [accessed in 05 October 2020]. Available at: https://iris.paho.org/ handle/10665.2/51739

5. Alvar J, Yactayo S, Bern C. Leishmaniasis and poverty. Trends Parasitol. 2006;22(12):552-557. Doi: 10.1016/j.pt.2006.09.004.

6. World Health Organization. Health in 2015: from MDGS, millennium development goals, to SDGS, sustainable development goals. [Internet]. Geneva: OMS; 2015 [accessed in 05 October 2020]. Available at: https://apps.who.int/iris/handle/10665/200009

7. Shaw J. The leishmaniases, survival and expansion in a changing world: a mini-review. Mem Inst Oswaldo Cruz. 2007;102(5):541-547.

8. Rangel EF, Carvalho BM, Costa SM, Lainson R, Shaw JJ. Sand fly vectors of American cutaneous leishmaniasis in Brazil. $1^{\circ} \mathrm{Ed}$. Rio de Janeiro: Springer, Cham; 2018:341-380.

9. El-Sayed A, Kamel M. Climatic changes and their role in emergence and re-emergence of diseases. Environ Sci Pollut Res Int. 2020;27(18):22336-22352. Doi: 10.1007/s11356-020-08896-w.

10. Carvalho BM, Rangel EF, Ready PD, Vale M.M. Ecological niche modelling predicts southward expansion of Lutzomyia (Nyssomyia) flaviscutellata (Diptera: Psychodidae: Phlebotominae), vector of Leishmania (Leishmania) amazonensis in South America, under climatecChange. PLoS ONE. 2015;10(11):e0143282. Doi: https://doi.org/10.1371/journal.pone.0143282.

11. Costa SM, Cordeiro LP, Rangel EF. Environmental suitability for Lutzomyia (Nyssomyia) whitmani (Diptera: Psychodidae: Phlebotominae) and the occurrence of American cutaneous leishmaniasis in Brazil. Parasites \& Vectors. 2018;11(155):e0143282.

12. Buzanovsky LP, Sanchez-Vazquez MJ, Maia-Elkhoury ANS, Werneck GL. Major environmental and socioeconomic determinants of cutaneous leishmaniasis in Brazil: a systematic literature review. Rev Soc Bras Med Trop. 2020;53:e20190291. Doi: https://doi.org/ $10.1590 / 0037-8682-0291-2019$
13. Maia-Elkhoury ANS, Valadas SYOB, Puppim-Buzanovsky L, Rocha F, Sanchez-Vazquez MJ. SisLeish: a multi-country standardized information system to monitor the status of Leishmaniasis in the Americas. PLoS Negl Trop Dis. 2017;11(9):e0005868. Doi: https:// doi.org/10.1371/journal.pntd.0005868

14. Worldclim [Internet]. Historical climate data. [updated in January 2020; accessed in 19 June 2020]. Available at: https://www.world clim.org/data/worldclim21.html

15. Food and Agriculture Organization [Internet]. Occurence of forest [updated in May 2007; accessed in 19 June 2020]. Available at: http:/ / www.fao.org:80/geonetwork/srv/en/resources.get?id= 14066\&fname=Map5_1.zip\&access=private

16. European Space Agency[ Internet]. GlobCover 2009 [updated in December 2010; accessed in 19 June 2020]. Available at: http:/ / due. esrin.esa.int/page_globcover.php

17. U.S Geological Survey [Internet]. Mineral resources online spatial sata [accessed in 19 June 2020]. Available at: https://mrdata.usgs. gov/\#mineral-resources

18. Saboyá-Díaz MI, Betanzos-Reyes AF, West SK, Muñoz B, Castellanos LG, Espinal M. Trachoma elimination in Latin America: prioritization of municipalities for surveillance activities. Rev Panam Salud Publica. 2019;43:e93. Doi: https://doi.org/10.26633/RPSP. 2019.93

19. Baston D. Exactextractr: fast extraction from raster datasets using polygons. R package version 0.3.0. [accessed in 05 August 2020]. Available at: https://CRAN.R-project.org/package=exactextractr. 2020

20. R Core Team [Internet]. R: a language and environment for statistical computing. R Foundation for Statistical Computing, Vienna, Austria [accessed in 04 August 2020]. Available at: https://www. R-project.org/

21. Husson F, Josse J, Pagès J. Principal component methods hierarchical clustering - partitional clustering: why would we need to choose for visualizing data? Tech Rep Appl Math Dep. 2010:1-17.

22. Husson F. Exploratory multivariate analysis by example using R. J Stat Softw. 2011;40.

23. Lë S, Josse J, Husson F. FactoMineR: an R package for multivariate analysis. J Stat Softw. 2008;25(1):1-18. Doi: 10.18637/jss.v025.i01

24. Armstrong MP, Xiao N, Bennett DA. Using genetic algorithms to create multicriteria class intervals for choropleth maps. Ann Assoc Am Geogr. 2003;93(3):595-623. Doi: https://doi.org/10.1111/ 1467-8306.9303005

25. Jenks G. Optimal data classification for choropleth maps. Kansas: University Dept. of Geography-Meteorology: 1977. 
26. World Health Organization. Ending the neglect to attain the sustainable development goals: a road map for neglected tropical diseases 2021-2030. Geneva: OMS; 2020. Available at: https://www.who.int/ neglected_diseases/resources/who-ucn-ntd-2020.01/en/

27. Pérez-Flórez M, Ocampo CB, Valderrama-Ardila C, Alexander N. Spatial modeling of cutaneous leishmaniasis in the Andean region of Colombia. Mem Inst Oswaldo Cruz. 2016;111(7):433-442. Doi: https://doi.org/10.1590/0074-02760160074

28. Colston J, Saboyá M. Soil-transmitted helminthiasis in Latin America and the Caribbean: modelling the determinants, prevalence, population at risk and costs of control at sub-national level. Geospat Health. 2013;7(2):321-40. Doi: 10.4081/gh.2013.90

29. Salomon OD. Instructions on how to make an outbreak of American cutaneous leishmaniasis. J Trop Med Health. 2019; 3:146. doi: 10.29011/2688-6383.000146

30. Chavy A, Nava AFD, Luz SLB, Ramírez JD, Herrera G, Dos Santos $\mathrm{TV}$, et al. Ecological niche modelling for predicting the risk of cutaneous leishmaniasis in the neotropical moist forest biome. PLoS Negl Trop Dis. 2019;13(8):e0007629. Doi: 10.1371/journal.pntd.0007629

31. Rodrigues MGA, Sousa JDB, Dias ÁLB, Monteiro WM, Sampaio VS. The role of deforestation on American cutaneous leishmaniasis incidence: spatial-temporal distribution, environmental and socioeconomic factors associated in the Brazilian Amazon. Trop Med Int Health. 2019;24(3):348-355. Doi: 10.1111/tmi.13196

32. Bonilla-Aldana DK, Suárez JA, Franco-Paredes C, Vilcarromero S, Mattar S, Gómez-Marín JE, et al. Brazil burning! What is the potential impact of the Amazon wildfires on vector-borne and zoonotic emerging diseases? A statement from an international experts meeting. Travel Med Infect Dis. 2019;31:101474. Doi: 10.1016/j. tmaid.2019.101474

33. Rebêlo JMM, Moraes JLP, Cruz GBV, Andrade-Silva J, Bandeira MDCA, Oliveira YNP, Santos CLCD. Influence of deforestation on the community structure of sand flies (Diptera: Psychodidae) in Eastern Amazonia. J Med Entomol. 2019;56(4):1004-1012. Doi: 10.1093/jme/tjz014

34. Hashiguchi Y, Gomez LEA, Cáceres AG, Velez LN, Villegas NV, Hashiguchi $\mathrm{K}$, et al. Andean cutaneous leishmaniasis (Andean-CL, uta) in Peru and Ecuador: the vector Lutzomyia sand flies and reservoir mammals. Acta Trop. 2018; 178:264-275. Doi: 10.1016/j. actatropica.2017.12.008

35. Hernández AM, Gutierrez JD, Xiao Y, Branscum AJ, Cuadros DF. Spatial epidemiology of cutaneous leishmaniasis in Colombia: socioeconomic and demographic factors associated with a growing epidemic. Trans R Soc Trop Med Hyg. 2019;113(9):560-568. doi: $10.1093 / \mathrm{trstmh} / \mathrm{trz} 043$
36. Torres-Slimming P. Globalización, el proyecto Camisea y la salud de los matsiguengas. Rev Peru Med Exp Salud Publica. 2010;27(3):458-65.

37. Gutiérrez JD, Martínez-Vega R, Ramoni-Perazzi J, Diaz-Quijano FA, Gutiérrez R, Ruiz FJ, et al. Environmental and socio-economic determinants associated with the occurrence of cutaneous leishmaniasis in the northeast of Colombia. Trans R Soc Trop Med Hyg. 2017;111(12):564-571. Doi: 10.1093/trstmh/try011

38. Guerra JAO, Guerra MGVB, Vasconcelos ZS, Freitas NS, Fonseca FR, da Silva Júnior RC, et al. Socioenvironmental aspects of the Purus Region - Brazilian Amazon: Why relate them to the occurrence of American tegumentary leishmaniasis? PLoS One. 2019;14(2): e0211785. Doi: https://doi.org/10.1371/journal.pone.0211785

39. de Bustamante MC, Pereira MJ, Schubach Ade O, da Fonseca AH. Epidemiological profile of cutaneous leishmaniasis in an endemic region in the State of Rio de Janeiro, Brazil. Rev Bras Parasitol Vet. 2009;18(3):34-40. Doi: https://doi.org/10.4322/rbpv.01803006

40. Quintana MG, Salomón OD, De Grosso MS. Distribution of phlebotomine sand flies (Diptera: Psychodidae) in a primary forest-crop interface, Salta, Argentina. J Med Entomol. 2010;47(6):1003-10. Doi: https://doi.org/10.1603/ME09072

41. Zúñiga PM. Dimensión sociocultural de la leishmaniasis cutánea. Estados Unidos de América: Editorial Académica Española; 2015.

42. Chaves LF, Cohen JM, Pascual M, Wilson ML. Social exclusion modifies climate and deforestation impacts on a vector-borne disease. PLoS Negl Trop Dis. 2008;2(1):e176. Doi: https://doi.org/10.1371/ journal.pntd.0000176

43. Eid D, Guzman-Rivero M, Rojas E, Goicolea I, Hurtig AK, Illanes D, et al. Risk factors for cutaneous leishmaniasis in the rainforest of Bolivia: a cross-sectional study. Trop Med Health. 2018; 46:9. Doi: 10.1186/s41182-018-0089-6

44. Gómez LE, Corredor A. Caracterización sociocultural y epidemiológica de un foco de leishmaniasis cutánea en Cimitarra, Santander. Rev Salud Publica 2000;2(3):261-271.

45. Cruz CB, da Silva MA, Afonso WBB. Perfil da população acometida por Leishmaniose tegumentar americana em Barra do Garças - MT. Revista Eletrônica Interdisciplinar. 2017;18(2):84-90.

Manuscript (original in Spanish) received on 26 November 2020. Accepted for publication, following review, on 19 March 2020 


\section{Interacción entre los determinantes medioambientales y socioeconómicos para el riesgo de leishmaniasis cutánea en América Latina}

RESUMEN Objetivo. Determinar y caracterizar áreas de riesgo potencial de la ocurrencia de leishmaniasis cutánea (LC) en América Latina (AL).

Método. Estudio observacional ecológico con unidades de observación definidas por municipios con transmisión de LC entre 2014-2018. Se utilizaron variables medioambientales y socioeconómicas disponibles para al menos $85 \%$ de los municipios, combinados en una sola base de datos, a través del software R. Se combinó la metodología de análisis de componentes principales con un análisis de conglomerados jerárquicos para la formación de conglomerados de municipios en función de su similitud. Se estimó el V-test para definir la asociación positiva o negativa de las variables con los conglomerados y separación por divisiones naturales para determinar cuáles contribuyeron más a cada conglomerado. Se incorporaron los casos para atribuir el riesgo de LC para cada conglomerado.

Resultados. Se incluyeron en el estudio 4951 municipios con transmisión de LC (36,5\% del total en AL) y se definieron siete conglomerados por su asociación con 18 variables medioambientales y socioeconómicas. El riesgo histórico de LC se asocia de manera positiva y en forma decreciente con los conglomerados Amazónico, Andino y Sabana; y de manera negativa con los conglomerados Boscoso/perenne, Boscoso/ cultivo y Boscoso/poblado. El conglomerado Agrícola no reveló ninguna asociación con los casos de LC. Conclusiones. El estudio permitió identificar y caracterizar el riesgo de LC por conglomerados de municipios y conocer el patrón propio epidemiológico de distribución de la transmisión, lo que proporciona a los gestores una mejor información para las intervenciones intersectoriales para el control de la LC.

Palabras clave

Leishmaniasis cutánea; análisis por conglomerados; América Latina

\section{Interação entre os determinantes ambientais e socioeconômicos para o risco de leishmaniose cutânea na América Latina}

RESUMO

Objetivo. Determinar e caracterizar as áreas de risco de ocorrência de leishmaniose cutânea na América Latina.

Método. Estudo observacional ecológico com unidades de observação definidas por municípios com transmissão de leishmaniose cutânea entre 2014 e 2018. Foram usadas as variáveis ambientais e socioeconômicas disponíveis em $85 \%$ ou mais dos municípios, reunidas em uma única base de dados com o uso do software R. A metodologia de análise de componentes principais foi combinada a uma análise de conglomerados com agrupamento hierárquico para formar conglomerados de municípios por semelhança. $\mathrm{O}$ teste $\mathrm{V}$ foi usado para estabelecer a associação (positiva ou negativa) das variáveis com os conglomerados e uma separação por divisões naturais foi usada para determinar as variáveis que mais contribuíram em cada conglomerado. Os casos foram incluídos para avaliar o risco de leishmaniose cutânea em cada conglomerado.

Resultados. A amostra do estudo compreendeu 4.951 municípios com transmissão de leishmaniose cutânea (36,5\% do total na América Latina). Foram definidos sete conglomerados por apresentarem associação com 18 variáveis ambientais e socioeconômicas. Foi observada associação positiva e decrescente do risco histórico de leishmaniose cutânea com os conglomerados Amazônico, Andino e Savana e negativa com os conglomerados Mata/perene, Mata/cultivo e Mata/povoado. O conglomerado Agrícola não demonstrou associação com casos de leishmaniose cutânea.

Conclusões. Este estudo permitiu identificar e caracterizar o risco de leishmaniose cutânea por conglomerados de municípios e conhecer o padrão epidemiológico de distribuição da transmissão da doença, oferecendo às autoridades dados melhores para subsidiar as intervenções intersetoriais para o controle da leishmaniose cutânea.

Palavras-chave Leishmaniose cutânea; análise por conglomerados; América Latina. 